\title{
Iron, magnesium and ischaemic heart disease
}

\author{
BY PETER C. ELWOOD \\ MRC Epidemiology Unit, Llandough Hospital, Penarth, \\ South Glamorgan CF64 $2 X W$
}

Interest has focused recently on a number of micronutrients which are of likely relevance to ischaemic heart disease. Two of these, $\mathrm{Fe}$ and $\mathrm{Mg}$, are essential trace elements and the importance of both in ischaemic heart disease is at present under close scrutiny.

\section{IRON}

There are a number of ways in which Fe could be of relevance to ischaemic heart disease (IHD). A high dietary intake can raise circulating haemoglobin level and lead to an increase in blood and plasma viscosity, which in turn are strong predictors of IHD events (Yarnell et al. 1991). On the other hand, a low circulating haemoglobin level consequent on anaemia has been shown to be associated with a proliferation in the anastomostic network of the coronary vessels (Zoll et al. 1951) which could be life-saving in coronary thrombosis. A further way in which $\mathrm{Fe}$ is of relevance to heart disease arises from the possibility that Fe may promote free-radical production, particularly during reperfusion of the anoxic myocardium following infarction (Biemond et al. 1986). Others have also suggested that free $\mathrm{Fe}$ may be more generally involved as a catalyst in free-radical generation and, therefore, in the promotion of atherosclerosis through the oxidation of lipids within the vessel wall (Cross et al. 1987; Salonen et al. 1992).

There are a number of measures of body Fe status, and it is of interest to examine the predictive power of each of these for IHD events. Measures include dietary Fe intake, $\mathrm{Fe}$ in transport (serum $\mathrm{Fe}$ and transferrin saturation), Fe in haemoglobin (haemoglobin concentration and packed cell volume), and storage Fe (usually estimated from serum ferritin). Fe is widely distributed throughout the diet and consequently it is difficult to estimate total intake. A further difficulty comes from the fact that dietary Fe involves two groups of sources, inorganic salts and haem-, or protein-bound Fe in meat and other animal food products. These are seldom distinguished in dietary intake studies, and this is perhaps unfortunate because haem-Fe is absorbed with much greater efficiency than inorganic Fe. Perhaps because of the difficulties in estimating dietary $\mathrm{Fe}$, there have been few attempts to examine associations with IHD. Only one, the Kupio study (Salonen et al. 1992), has detected a significant association of a 5\% increase in the risk of an IHD event for each $1 \mathrm{mg}$ of dietary Fe intake. This result, however, is based on a relatively small cohort of 1931 men in whom only fifty-one heart-disease events occurred during a 3-year follow-up, while three larger cohort studies failed to find any such association (Ascherio et al. 1994; Morrison et al. 1994; Sempos et al. 1994). In other studies, estimates of Fe status have been based on serum Fe or transferrin saturation (Magnusson et al. 1994; Morrison et al. 1994; Sempos et al. 1994). The evidence from these studies on associations with IHD are totally inconsistent.

The easiest measures of Fe status are, of course, haemoglobin level and packed cell volume, and the relationships between these variables and IHD have been examined in 
Table 1. Haemoglobin level and heart disease based on 2334 men aged 45-59 years being followed in the Caerphilly Prospective Study of Heart Disease and Stroke

(Estimates of haemoglobin level were made at baseline and 312 heart disease events (ischaemic heart disease (IHD) death or myocardial infarction) occurred during 10 years of follow-up)

\begin{tabular}{ccc}
\hline $\begin{array}{c}\text { Fifths of } \\
\text { Hb level }\end{array}$ & $\begin{array}{c}\text { Relative odds } \\
\text { of an IHD event }\end{array}$ & $\begin{array}{c}\text { Relative odds standardized for } \\
\text { age, smoking and prevalent } \\
\text { heart disease }\end{array}$ \\
\hline Highest & 1.0 & 1.0 \\
2nd & 1.0 & 1.1 \\
Middle & 1.0 & 1.0 \\
4th & 1.6 & 1.6 \\
Lowest & 1.3 & 1.2 \\
\hline
\end{tabular}

$\mathrm{Hb}$, haemoglobin

numerous studies. An overall interpretation is difficult because in many of the earlier studies inadequate attention was paid to the effect of possible confounding factors, in particular smoking, which is associated with elevated haemoglobin and packed cell volume levels, and an increased risk of IHD. Most of the major recent studies of male cohorts, including the Honolulu Heart Program (Carter et al. 1983), the follow-up of NHANES I (Sempos et al. 1994) and the Health Professionals Study (Ascherio et al. 1994) failed to find any association once allowance had been made for relevant confounding factors. Our own cohort study, the Caerphilly Prospective Study of Heart Disease and Stroke, also gives no evidence (Table 1), indeed there is a suggestion that lower levels of haemoglobin may indicate a higher risk of IHD (not significant).

In conclusion, although no formal meta-analyses seem to have been done, an epidemiologist is unlikely to be impressed by the evidence on body $\mathrm{Fe}$ status, however measured, and risk of IHD.

\section{MAGNESIUM}

$\mathrm{Mg}$ is the second most abundant intracellular cation, next to $\mathrm{K}$. It is in highest concentration in the most active tissues, i.e. brain, heart, liver and kidney, and about one-third of the total body Mg is in skeletal and cardiac muscle (Rude, 1989). Within the heart, it slows conduction through the atrioventricular node with a reduction in clinically significant arrhythmias after acute myocardial infarction (Woods, 1991). It may also protect the myocardium both against ischaemic injury and against reperfusion injury (Woods, 1991). Further effects of $\mathrm{Mg}$ which are likely to be protective include an inhibition of platelet function (Adams \& Mitchell, 1979) and coronary vasodilatation possibly through the inhibition of the contraction of smooth muscle and the production of endothelium-derived relaxing factor (EDRF) (Gold et al. 1990).

The estimation of body $\mathrm{Mg}$ status is undoubtedly difficult and has not been studied widely. The element is largely intracellular and, thus, serum levels are likely to be of little clinical relevance. On the other hand, it is highly mobile in the tissues and, for example, it rapidly moves out of infarcted tissue. Dietary $\mathrm{Mg}$, however, comes from a relatively small number of food items, and the consumption of these particular food 
Table 2. Sources of dietary magnesium: the average contribution (\%) to the total dietary Mg intake made by various food items, based on 2398 food-frequency questionnaires given to men in the Caerphilly Prospective Study of Heart Disease and Stroke*

\begin{tabular}{lr}
\hline Fruit and vegetables & 24 \\
Bread & 24 \\
Eggs and dairy produce & 17 \\
Alcoholic drinks & 14 \\
Meat & 8 \\
Fish & 3 \\
Other foods & 10 \\
\hline
\end{tabular}

* In some areas $\mathrm{Mg}$ in hard water can increase total daily intake by at least $20 \%$ (Anderson et al. 1975).

items can be estimated with fair precision. Table 2 lists the main sources of $\mathrm{Mg}$ and indicates the average contribution of each to the total intake in a representative population sample of men in Wales. While the estimation of a dietary item cannot be said to be precise, estimations of $\mathrm{Mg}$ intake are certainly likely to be better than those of $\mathrm{Fe}$ intake. Furthermore, within the cohort of men in Wales, estimations of intake made from 7-d weighed intake records were found to correlate reasonably well with estimates based on a food-frequency questionnaire $(r 0 \cdot 4, P<0 \cdot 001)$ and estimates made from the latter appear to be fairly stable within individuals over time ( $r$, between two sets of estimations, made 5 years apart, $0 \cdot 4, P<0 \cdot 001$ ).

Epidemiological evidence relating $\mathrm{Mg}$ to IHD comes from several sources. First, a number of studies have shown that tissue $\mathrm{Mg}$, estimated in samples of myocardium taken post-mortem, is substantially reduced in subjects whose death had been certified as due to IHD (Iseri et al. 1952; Chipperfield \& Chipperfield, 1973; Elwood et al. 1980). Second, a number of clinical trials have demonstrated a reduction in mortality following myocardial infarction from an intravenous infusion of a $\mathrm{Mg}$ salt. The most important of these is the trial known as the second Leicester Intravenous Magnesium Intervention Trial (LIMIT-2), in which 2316 post-infarct patients were randomized to receive either an intravenous $\mathrm{Mg}$ salt, or physiological saline $(9 \mathrm{~g} \mathrm{NaCl} / \mathrm{l}$; Woods et al. 1992). The primary outcome measure was $28 \mathrm{~d}$ mortality post-infarction, and this was reduced by $24 \%$ in the group of patients given $\mathrm{Mg}$. The evidence from this trial, and from a number of smaller previous trials which indicated benefit from $\mathrm{Mg}$, has been challenged by the results of ISIS-4, which tested the effect of a Mg infusion in over 50000 post-infarction patients (ISIS Collaborative Group, 1993). In this, an excess of $4 \%$ deaths by $35 \mathrm{~d}$ after infarction (statistically not significant) contrasts sharply with the reduction reported from the LIMIT-2 (Woods et al. 1992) and other trials.

To nutritionists and to epidemiologists, however, the question of greatest interest is whether or not $\mathrm{Mg}$ is protective in normal subjects in the general population. Relevant evidence seems to be extremely sparse, and to date it would seem that dietary Mg intake data have been reported from only one large cohort study (The Caerphilly and Speedwell Collaborative Group, 1984). The Caerphilly Prospective Study is based on a cohort of 2512 older men who have been followed for 10 years. While preliminary evidence suggested a protective role for $\mathrm{Mg}$, further examination of the data suggests that a negative association between dietary $\mathrm{Mg}$ intake and subsequent IHD events, may be totally explained by confounding variables, in particular alcohol intake (Table 3). 
Table 3. Dietary magnesium and heart disease: mean $\mathrm{Mg}$ intakes for men in the Caerphilly Prospective Study of Heart Disease and Stroke cohort who died from an acute myocardial infarction (ICD 410; $M I$ ), suffered a non-fatal myocardial infarct, or experienced no myocardial infarction during a 10-year follow-up

\begin{tabular}{llccc}
\hline & & \multicolumn{3}{c}{ Mean Mg intake (mg/d) } \\
\cline { 2 - 4 } & & 1 & 2 & 3 \\
\hline Outcome & 242 & 256 & 265 \\
Acute MI death & 259 & 256 & 260 \\
Non-fatal MI & 265 & 265 & 264 \\
\hline
\end{tabular}

1, Standardized for age and smoking: 2 , alcohol intake added; 3 , energy intake added: IHD, ischaemic heart disease.

Table 4. Serum and erythrocyte magnesium and heart disease based on 2046 men, aged 45-59 years, followed for 5 years*

\begin{tabular}{|c|c|c|c|}
\hline Outcome & $n$ & Serum $\mathrm{Mg}$ & Erythrocyte $\mathrm{Mg}$ \\
\hline Acute MI death & 38 & 0.82 & $5 \cdot 43$ \\
\hline Non-fatal MI & 93 & $0 \cdot 81$ & $5 \cdot 57$ \\
\hline No IHD event & 1905 & 0.83 & $5 \cdot 32$ \\
\hline & & $(\mathrm{SD}(0.06)$ & $(\operatorname{sD} 0.53)$ \\
\hline
\end{tabular}

MI, myocardial infarction: IHD, ischaemic heart discasc.

* Mg levels estimated at baseline.

Further confirmatory evidence comes from an absence of any predictive power of estimations of serum and erythrocyte $\mathrm{Mg}$. made 5 years into the study and, hence, evaluated against incident events during 5 years of follow-up (Table 4).

\section{CONCLUSION}

IHD is a multifactorial disease, and it is likely that many dietary factors are involved. The current interest in free radicals and in dietary antioxidants enormously heightens expectations of important associations with dietary items.

Wide media attention has been focused recently on Fe. following the report of an association between a measure of storage $\mathrm{Fe}$ (serum ferritin) and myocardial infarction (Salonen et al. 1992). Two larger studies gave no confirmation, however, and a wide range of studies of other measures of $\mathrm{Fe}$ status have given inconsistent, but largely negative, results.

It is even more difficult to assess the evidence on $\mathrm{Mg}$ and IHD. Expectations of benefit arise from a very large number of animal and laboratory studics, but two large trials of the beneficial effect of $\mathrm{Mg}$ in patients at high risk of death from heart disease have given results which are totally inconsistent. Preliminary evidence on the relevance of $\mathrm{Mg}$ in the general population is limited at present to a single cohort study and this gives no evidence of prediction for death by dietary $\mathrm{Mg}$, once allowance has been made for the effects of confounding factors, in particular alcohol. 


\section{REFERENCES}

Adams, J. H. \& Mitchell, J. R. A. (1979). The effect of agents which modify platelet behaviour and of magnesium ions on thrombus formation in vivo. Thrombosis and Haemostasis 42, 603-610.

Anderson, T. W., Neri. L. C., Schreiber, G. B., Talbot, F. D. F. \& Zdrojewski, A. (1975). Ischaemic heart disease, water hardness and myocardial magnesium. Canadian Medical Association Journal 113, $199-203$.

Ascherio, A., Willett, W. C., Rimm, E. B., Giovannucci, E. L. \& Stampfer. M. J. (1994). Dietary iron intake and risk of coronary disease among men. Circulation 89, 969-974.

Biemond, P., Swaak, A. J., Beindorff, C. M. \& Koster, J. F. (1986). Superoxide-dependent and -independent mechanisms of iron mobilization from ferritin by xanthine oxidase: implications for oxygen-free-radicalinduced tissue destruction during ischaemia and inflammation. Biochemistry Journal 239, 169-173.

Carter, C., McGee, D., Reed, D., Yano, K. \& Ftemmermann, G. (1983). Haematocrit and the risk of coronary heart disease: the Honolulu Heart Program. American Heart Journal 105, 674-679.

Chipperfield, B. \& Chipperfield, J. R. (1973). Heart muscle magnesium. potassium and zinc concentrations after sudden death from heart disease. Lancet ii, 293-296.

Cross, C. E. Halliwell, B., Borish, E. T., Pryor, W. A.. Saul, R. L., McCord, J. M. \& Harman, D. (1987). Oxygen radicals and human disease. Annals of Internal Medicine 107, 526-545.

Flwood, P. C., Sweetnam, P. M., Beasley. W. H., Jones, D. \& France, R. (1980). Magnesjum and calcium in the myocardium: cause of death and area differences. Lancet ii, 720-722.

Gold, M. E. Buga, G. M., Wood, K. S., Byrns, R. E., Chaudhuri, G. \& Ignarro, L. J. (1990). Antagonistic modulatory roles of magnesium and calcium on release of endothelium-derived relaxing factor and smooth muscle tone. Circulation Research 66, 355-366.

Iscri. L. T., Alexander, L. C., McCaughey, R. S., Boyle, A. J. \& Myers, G. B. (1952). Water and electrolyte content of cardiac and skeletal muscle in heart failure and myocardial infarction. American Heart Journal 43, 215-227.

ISIS Collaborative Group (1993). ISIS-4: randomised study of intravenous magnesium in over 50.000 patients with suspected acute myocardial infarction. Circulation 88, Suppl. I, 292.

Magnusson, M. K., Sigfusson, N., Sigvaldason, H., Johannesson, G. M., Magnusson, S. \& Thorgeirsson. G. (1994). Low iron-binding capacity as a risk factor for myocardial infarction. Circulation 89, 102-108.

Morrison, H. I., Semenciw, R. M., Mao, Y. \& Wigle, D. T. (1994). Serum iron and risk of fatal acute myocardial infarction. Epidemiology 5, 243-246.

Rude. R. (1989). Physiology of magnesium metabolism and the important role of magnesium in potassium deficiency. American Journal of Cardiology 63, 31G-34G.

Salonen. J. T., Nyyssönen, K., Korpela, H., Tuomilehto, J., Seppänen, R. \& Salonen, R. (1992). High stored iron levels are associated with excess risk of myocardial infarction in Eastern Finnish men. Circularion 86. 803-811.

Sempos, C. T., Looker, A. C.. Gillum, R. F. \& Makuc, D. M. (1994). Body iron stores and the risk of coronary heart disease. New' England Journal of Medicine 330, 1119-1124

The Caerphilly and Speedwell Collaborative Group (1984). Caerphilly and Speedwell collaborative heart disease studies. Journal of Epidemiology and Community Health 38, 259-262.

Woods, K. L. (1991). Possible pharmacological actions of magnesium in acute myocardial infarction. British Journal of Clinical Pharmacology 32, 3-10.

Woods, K. L., Fletcher, S., Roffe, C. \& Haider. Y. (1992). Intravenous magnesium sulphate in suspected acute myocardial infarction: results of the second Leicester Intravenous Magnesium Intervention Trial (LIMIT-2). Lancet 339, 1553-1558.

Yarnell, J. W. G., Baker, I. A., Sweetnam, P. M. Bainton, D., O'Brien, J. R., Whitehead. P. J. \& Elwood, P. C. (1991). Fibrinogen, viscosity, and white blood cell count are major risk factors for ischaemic heart disease. The Caerphilly and Speedwell Collaborative Heart Disease Studics. Circulation 83, 836-844.

7oll. P. M., Wessler. S. \& Schlesinger, J. (1951). Inter-arterial coronary anastamoses in the human heart with particular reference to anaemia and relative cardiac anoxia. Circulation 4, 797-815. 